April 2010

\title{
The Devil in the Details: "Life Force Atrocities" and the Assault on the Family in Times of Conflict
}

Elisa von Joeden-Forgey

Follow this and additional works at: https://digitalcommons.usf.edu/gsp

\section{Recommended Citation}

von Joeden-Forgey, Elisa (2010) "The Devil in the Details: "Life Force Atrocities" and the Assault on the Family in Times of Conflict," Genocide Studies and Prevention: An International Journal: Vol. 5: Iss. 1: Article 2.

Available at: https://digitalcommons.usf.edu/gsp/vol5/iss1/2

This Articles is brought to you for free and open access by the Open Access Journals at Digital Commons @ University of South Florida. It has been accepted for inclusion in Genocide Studies and Prevention: An International Journal by an authorized editor of Digital Commons @ University of South Florida. For more information, please contact digitalcommons@usf.edu. 


\title{
The Devil in the Details: "Life Force Atrocities" and the Assault on the Family in Times of Conflict
}

\author{
Elisa von Joeden-Forgey \\ University of Pennsylvania
}

This article introduces the idea of "life force atrocities" and investigates the role they have played in twentieth-century genocides, arguing that genocide is a gendered crime intimately associated with institutions of reproduction. Using examples from established cases of genocide, such as the Armenian genocide, the Holocaust, Bosnia, and Rwanda, as well as from conflicts not generally understood as genocides, such as Sierra Leone and the Democratic Republic of Congo (DRC), the article outlines two types of life force atrocities that have been common features of these conflicts: inversion rituals and ritual desecrations. Each of these instances of ritualized atrocity targets the family unit within victim groups and betrays a preoccupation with the group's life force in its physical and symbolic dimensions. Since life force atrocities play on gender roles and hierarchies to torture family members, this article focuses on the relational way in which génocidaires instrumentalize gendered violence to destroy the sacred realm of the family as part of the larger effort to destroy a group. The presence of life force atrocities during a conflict can therefore function as an early warning sign of a genocidal logic at some level of the political or military hierarchy. They also offer us insight into the state of mind of the perpetrators who, I argue, see themselves as engaged in a battle with the generative force of the victim group. In some cases, as in Sierra Leone and the DRC, this battle becomes generalized, and soldiers target the life force as such, attempting to destroy (via families) the civilian world in its totality.

Key words: gender, rape, family, reproduction, genocide, prevention, life force atrocity

"Our family tree was obliterated by the genocide. That's where our family begins." This is how Art Tonoyan, a graduate student of religious studies and grandson of survivors of the Armenian genocide, described the genocide's impact on his family. Speaking to the Waco Tribune-Herald in 2005, he told of how his grandfather and grandmother were orphaned by the genocide. His grandmother was too young to remember the details of her orphaning; his grandfather, as a little boy of eight, was forced to watch as Turkish soldiers raped, tortured, and killed his parents and siblings in front of him. The soldiers told him that they would leave him alive so that, in their words, he could "see what we are capable of." He later witnessed the entire village being herded into a church and burned alive. "I will never forget my grandfather's eyes," Art Tonoyan told the reporter. "He was a very sad person. I rarely remember him smiling. He never got over seeing his family murdered." 1

As Tonoyan's family story shows, genocide, while directed at the destruction of larger groups, is a crime that is inextricably tied to families. What we hear repeatedly

Elisa von Joeden-Forgey, "The Devil in the Details: 'Life Force Atrocities' and the Assault on the Family in Times of Conflict." Genocide Studies and Prevention 5, 1 (April 2010): 1-19. (C) 2010 Genocide Studies and Prevention. doi:10.3138/gsp.5.1.1 
in the stories of survivors of twentieth-century genocides is the terrible way in which genocidal violence is embedded in the most sacred aspects of their family lives. This embedding is not just a matter of individual memory or of the transgenerational trauma that genocide can cause. It begins with genocide itself, with the intimate ways in which génocidaires target their victims. This is so much so that the perpetrators often become woven into the origin stories of survivors' families. We are acquainted with the two Turkish killers of Tonoyan's family, for example, because they addressed their young victim personally; they chose him to be the audience to their performance of genocidal violence, raping his mother and his sister in front of him before killing them. Embedded in this dramatization of their concept of power was a message - a message they were sending to him, as an Armenian child in 1915 Anatolia, and to the rest of the world; a message we are still receiving up to this day.

Unfortunately, the message witnessed by Tonoyan's grandfather is one that countless numbers of people have been forced to witness in the twentieth century alone. The scenario of power that the perpetrators enacted in front of the terrified little boy and their decision to let him live as a witness to their spectacle are characteristic of genocidal violence across widely disparate times and cultures. In this article I wish to examine this and other genocidal scenarios and the messages they are meant to send by looking at the integral role played by family institutions in genocidal patterns of violence. I argue that the crimes committed against Art Tonoyan's family members are examples of a specific kind of crime that can be called life force atrocity. For the purpose of definition, life force atrocity is a ritualized pattern of violence that targets the life force of a group by destroying both the physical symbols of its life force as well as its most basic institutions of reproduction, especially the family unit. It exists alongside and in conjunction with other, more frequently discussed, genocidal patterns of violence, and with them can act as evidence of an emerging genocidal logic during times of conflict.

The violent acts I will examine are often the most difficult to discuss, much less fathom. They involve two interrelated types of rituals: first, violent inversion rituals that seek to reverse proper hierarchies and relationships within families and thereby irrevocably to break sacred bonds. Such acts include forcing family members to watch the rape, torture, and murder of their loved ones and forcing them to participate in the perpetration of such crimes. The second type of ritual involved in genocidal violence against families is the ritual mutilation and desecration of symbols of group reproduction, including male and female reproductive organs, women's breasts as the sites of lactation, pregnant women as the loci of generative powers, and infants and small children as the sacred symbols of the group's future. ${ }^{2}$

This article will make the argument that understanding life force atrocities is crucial to understanding the genocidal process and how it differs from other instances of mass murder, most notably war. It treats life force atrocities outside of the frameworks of atrocity and rape in which they have long languished. Life force atrocities are not generic in nature, and they are not synonymous with "rape" or with "sexual violence," although they may involve both. They are directed at men as well as women, boys as well as girls, using each to inflict maximum damage to the spiritual core of those generative and foundational units we call families. They betray a specific state of mind among perpetrators, who are not merely engaged in killing but also in a subjective metaphysical struggle with the life force itself. When viewed from the perspective of life force atrocities, genocide appears to be a crime whose perpetrators are uniquely preoccupied with wresting power from that mysteri- 
ous force that accounts for human life on this planet, a violent appropriation that they demonstrate in the highly symbolic ways in which they kill.

\section{The Ritual Performance of Genocide}

The types of atrocities that I am calling life force atrocities are often cited as incontrovertible evidence of perpetrator perversity-and they are certainly that. But our understanding of them should not be left at this, or we risk treating patterned violence as incidental and, in the process, making invisible a key feature of genocide. Instead, when we single out these acts for sustained analysis, we are able to offer another means of identifying genocidal intent in the absence of documentary proof. Just as the US Atrocities Documentation Team recently has identified village razing, cattle slaughtering, mass rape, and the use of racist epithets during killing in Darfur as de facto evidence of genocidal intent on the part of Janjaweed militias and the Government of Sudan, ${ }^{3}$ the presence of specific acts of violence directed at families can also serve to alert us to the dangerous presence of genocidal logic in conflict situations-potentially at a very early stage in a conflict, before a full-blown root and branch genocide is in the works. Life force atrocities may signal-and act as evidence of-intent on the part of the state authorities in control of the conflict region, or they may offer a warning that a certain militia or cadre within an armed force is behaving genocidally.

Scholars have only recently begun to treat the ritual cruelties that characterize the "interim stage" of genocide as subjects in their own right that are in need of classification and clarification. The dismal and timeless character of genocidal cruelty has made it appear to be little more than an inchoate reminder of humanity's endless capacity for evil. When we consider that certain cruelties are repeated from one genocide to the next, however, and that they seem to share a deep symbolism, there suddenly appears to be a method to the madness. Much of the analytical work being done on the particularities of genocidal cruelty is going on within the framework of gender studies. ${ }^{4}$ The reason for this is because when one breaks victims down by biological sex, patterns of cruelty immediately suggest themselves and demand explanation. While the majority of this important work has focused on the different experiences of men and women during genocide, I intend to focus on how genocidal cruelty aims precisely at the ties that bind men and women together. The experiences of men and women within a victim group are inextricably related to one another by virtue of the perpetrator's intent.

A harrowing example from Rwanda shows how genocidal cruelty is relational, and how perpetrators use both inversion rituals and ritual desecration simultaneously to destroy family bonds in the process of targeting a defined group. The UN Secretary General's Special Representative to Rwanda in 1994, Shaharyar Khan, tells us that during the genocide,

the Interahamwe made a habit of killing young Tutsi children, in front of their parents, by first cutting off one arm, then the other. They would then gash the neck with a machete to bleed the child slowly to death but, while they were still alive, they would cut off the private parts and throw them at the faces of the terrified parents, who would then be murdered with slightly greater dispatch. ${ }^{5}$

The horrendous spectacle Khan describes is not simply an example of the evil of some very extreme sadists, though it is certainly that too. It was, as he notes, a "habit" among members of the Hutu killing squads, a kind of ritual practice. Thus, like rituals, it can be analyzed for the insights it offers us into the "culture" of the 
killers, insights generally not available in documents or in perpetrators' accounts of their own behavior.

Also, a similar preoccupation with generative symbols structured much of "interim stage" violence of the Holocaust. In fact, the Nazi death camp system was perhaps the most sustained and involved inversion ritual and ritual desecration in the history of genocide. The camp system was organized around the purpose not just of mass killing but also of turning life on its head, of creating a living world of death that was to be witnessed by the Nazis' victims before their own murder. ${ }^{6}$ Emblematic of this inverted world is the Nazis' treatment of Jewish children. As Daniel Goldhagen has put it, "Children, as a rule, were not allowed to stay alive in German camps (except ghettos) because, among other reasons, they symbolized the renewal and continuation of the Jewish people, a future which the Germans sought to obliterate emotionally and in deed."7 Jewish children were usually sent with their mothers or grandparents straight to the gas chambers, or, when the crematoria were overburdened, to open pits of fire. Babies born in the camps were immediately destroyed, along with their mothers. ${ }^{8}$

A shocking example of symbolic cruelty from this death-affirming world is the little ten-year-old Jewish boy who was personally trained to kill other Jewish inmates by Christian Wirth, the commander of the notorious "Clothing Works" camp near the Lublin ghetto. One survivor remembered:

I have personally seen that this SS commander led a Jewish boy, who was about 10 years old, whom he kept and whom he fed chocolate and other goodies, to kill with a machine gun here and there 2 or 3 Jews at a time. I myself stood about 10 meters away when this boy carried out such shootings. The SS commander, who rode a white horse and who had given a horse to the boy, joined in the shooting. These two human beings together killed-in my presence-among the several occasions some 50 to 60 Jews. Among the victims were also women. ${ }^{9}$

Other survivors reported that the boy had been made to kill his own parents. As Goldhagen notes, "Nothing could have driven home the point more painfully: the world had been turned upside down, and this was for the Jews a surreal place of pain and misery from which they were unlikely to emerge alive."10

These three examples of life force atrocity-from the Armenian genocide, Rwanda, and the Holocaust-each demonstrate how genocidal cruelty can be ritualized and aimed at symbols of generative powers and narratives of family integrity. In the Armenian case, a little boy was forced to watch the desecration of his mother and sister as well as their murder and that of his entire family and town. In the Rwandan case, ultimate symbols of the life force, little children, were singled out for unspeakable brutalities that focused on their generative organs while their own parents were forced to watch helplessly. In the case of the Clothing Works during the Holocaust, a little boy-the heartbreaking symbol of the Jewish community's future-was trained to kill that very community from which he came, possibly including his own parents. In each of these cases the inversion and desecration of sacred familial hierarchies are the primary organizing principles of the violence; they are the method to the madness.

Rituals, even genocidal ones, are, in the words of anthropologist Stanley Tambiah, "medium(s) for transmitting meaning, constructing social reality ... [and] for that matter, creating and bringing to life the cosmological scheme itself." 11 They are also powerful means of communication and of the production and reproduction of power. ${ }^{12}$ In peacetime, public rituals are generally aimed at the reaffirmation of 
long-standing collective values and structures. ${ }^{13}$ Genocidal ritual, in contrast, is aimed not at the reaffirmation but at the transgression of long-standing cultural truths. The cosmological scheme that it brings to life is an anti-cosmos, the embracing of an inverted world based on death and transgression rather than the maintenance of and respect for life.

Ordinary génocidaires often allude to this space of the anti-cosmos themselves when they refer to the time of killing as a separate universe, a madness, or a diabolic inspiration. During the genocide in the Nyamata district of Rwanda, for example, regular religious rituals were suspended and replaced with killing and festivities related to it. "During the killings," one génocidaire told the journalist Jean Hatzfeld, "we had not one wedding, not one baptism, not one soccer match, not one religious service like Easter. We did not find that kind of celebration interesting anymore. We did not care spit for that Sunday silliness. We were dead tired from work, we were getting greedy, we celebrated whenever we felt like it, we drank as much as we wanted." 14

The atrocities that result from this performance of the anti-cosmos are dramatizations of a particularly genocidal "scenario of power," according to which the perpetrators as doing battle not only with the individual lives of members of a targeted group but also with the very life force that brings them into being. This ultimate offense-not just of killing people, but of killing the very life force responsible for their existence-may account for some of the ecstasy of transgression that has been documented to exist among perpetrators at the time of the commission of such acts. ${ }^{15}$ Unlike staged public rituals, genocidal ritual is often not well organized or hierarchal, nor is it always ordered (or condoned) by the command structure of an army and state committing genocide. Many genocidal rituals are the innovations of welltrained killers and zealous militias, who then spread them though their charismatic leadership within the violence. The innovative nature of life force atrocity within specific genocidal processes makes it all the more interesting that we can find such similarities within the logic of genocidal cruelty across time and space.

As Christopher Browning has shown, the repeated performance of transgressiona performance that often includes mind-altering substances-can facilitate surprisingly quickly the normalization of atrocity by constructing new social realities and new values to go along with them. ${ }^{16}$ In this way, genocidal rituals are formally very similar to non-genocidal and even normatively legitimate desensitization processes involved in training people to kill, whether they be ordinary soldiers or professional assassins. What distinguishes genocidal violence from other types of collective killing and brutality is the obsession it shows for the life force in all of its worldly manifestations. If we look at the details of the atrocities committed by the Hutu Interahamwe against young children, for example, the focused assault on several different aspect of the life force become clear: children as physical proof of the community's future, parental love and protectiveness as the bond that promotes family and communal unity, and sexual organs as the biological conduits of life-giving powers. This hostility towards symbolic and physical manifestations of the life force is a theme running through many if not most of the forms of torture used by génocidaires in the process of killing.

If genocidal rituals institutionalize the transgression of mundane social norms, they do so for the specific purpose of the destruction of a "national, ethnical, racial or religious group," to use the language of Article II of the UN Convention on the Crime of Genocide. The fact that perpetrators see their victims as part of a larger organic community explains why so much of the violence committed during genocides 
is deeply preoccupied with generative symbols. For perpetrators, these symbolswhether they are people of a specific status (such as mothers, "battle-age men," or religious figures) or relationships (such as marital, parental, or filial bonds)-are points of access to the ultimate threat, which is that power that continues to give birth to the community in the first place. This deeply metaphysical aspect of the crime of genocide makes it rare to find among perpetrators well-articulated definitions of the victim group (the Nazis being a notable exception) or clearly articulated plans to destroy it in whole or in part. Instead, perpetrators will understand generative power in culturally and historically specific ways, and in many cases their understanding of it will be so deeply ingrained and taken for granted that it will never be made explicit, at least not in words.

One way in which perpetrators' understanding of and plans for their victims do emerge rather clearly is in the way they torment them. When the torment appears to seek to destroy not only the individual human being but also that power that made him/her and what he/she (in the perpetrators' mind) essentially is, then I would argue a genocidal logic is at work at some level of the conflict. By looking at the devil that is clearly in the details of genocidal cruelty, we can better separate genocide from other crimes with which they share a superficial similarity.

\section{The Family Theater of Genocidal Violence}

The fact that the family takes such center stage in the enactment of genocidal cruelty can be explained in a variety of ways. The family is the social institution that organizes the life force of groups, so exploiting the family is one way that perpetrators express genocidal rage. ${ }^{17}$ Families focus, channel, and organize the life force of groups in several ways. They organize, of course, the basic reproduction of human life-the bringing of children in to the world. They also are the central sites of cultural and ethical or religious education, especially in children's early years. Furthermore, they are the creative centers of emotional and spiritual life; in families, children (ideally at least) first learn love, tenderness, loyalty, and responsibility. All of this creation is founded upon certain norms and taboos, which génocidaires target as a core locus of their obsessions. Furthermore, members of a targeted group are frequently found in households at the time of the attack, so the family unit also becomes a convenient site for the performance of genocidal rage.

When we look at genocide through the lens of a perpetrator's obsession with family life and generative power, we see clearly the central importance of what Michael Sells has called "desecration" to the crime itself. In all of the cases of inversion ritual and ritual desecration I have discussed thus far, the killers showed a diabolical creativity in the ways they tortured their victims in excess of-and, in some cases, instead of-physically killing them. These tortures were, I believe, intended to demonstrate to the victims the radical, annihilatory nature of the perpetrators' designs. The desecration of families and family life in genocides therefore demonstrates a deep level of intent on the part of the perpetrators, a commitment to destruction so total that it exceeds physical killing. Psychologists have pointed out the extent to which genocidal violence is patterned and linked to psychological processes. Alan Jacobs, for example, has written about perpetrators' obsession with and dependence on mass graves for their own sense of well-being. Mass graves become a necessary symbol of their power over death, of their "onliness." ${ }^{18}$ In a similar fashion, I would propose that violence against family bonds and institutions, as well as against the physical symbols of generative powers, works to express a particularly genocidal 
rage against the life force, a zero-sum battle against creation that is fought through the institutions that respect and nurture it.

Because of the multiple ways in which the family organizes the reproduction of the group, people are often singled out for gendered forms of torture based on their perceived and actual family roles. This was perhaps most clear during the genocide in Bosnia, where inversion rituals, mutilations of generative symbols, and genocidal rape were used with particular frequency and ubiquity. While the majority of Bosniaks killed were "battle age" men, and the majority of Bosniaks raped and expelled were women and children, the atrocities that accompanied this gendered division struck at the very heart of what ties men and women together, the family. Thus, fathers were forced to watch their daughters raped, husbands to watch their pregnant wives' bellies eviscerated, mothers had sons wrenched from their arms to be killed. The importance that the Serbs placed on the male role in reproduction seems in fact to have led to a particular frequency of sexual torture of men, including brutal castrations and coerced father-son rapes. According to one Croatian psychiatrist and survivor of a Serb concentration camp, men were beaten on the genitals while being told "You are never going to give birth to any more little Croats [or Muslims]." 19

The Bosnian case shows how important it is that we look beyond gender and ethnicity when assessing the nature of political violence and consider the victims' families and reproductive status. A clear example of a reproductive group that is singled out for particularly gruesome tortures during genocide is pregnant women, who are targeted because they are the living, breathing carriers of the life force inside of them. Pregnant women-commonly viewed as the most harmless of civilians-are, for génocidaires, a direct and double threat: they are themselves agents of creation rather than destruction, and as creators they threaten the goal of annihilation of the targeted group. In all genocides it appears that pregnant women have faced immediate death by evisceration, and their unborn children and infants have been killed in unimaginably brutal ways, often being smashed against the ground or rocks or used for target practice. ${ }^{20}$ This is frequently done in front of the restrained husbands and fathers.

In her pathbreaking article on the Bosnian genocide, "Turning Rape into Pornography," Catharine MacKinnon reports that a Bosnian Muslim soldier, whom she calls "Haris," told her that

he watched a man and a woman-who appeared to be seven or eight months pregnantbeing taken to a clearing in the woods. The woman was tied vertically to a cross, legs pressed together and arms extended. They ripped her pregnant belly open with a knife. "It was alive ... it moved." The woman took about 15 minutes to die. The man, apparently her husband and the father of the baby, was bound to a nearby tree and forced to watch. The attackers attempted to force him to eat the baby's arm. Then "they hacked him up, cut the flesh on him so that he would bleed to death." While they were doing this, they were laughing ... "We're going to slaughter all of you. This is our Serbia." $" 1$

The following is a description of Janjaweed atrocities in Darfur, from the photographer and former US Marine Brian Steidle, whose story has been told in the recent documentary The Devil Came on Horseback. His description of the violence is a description of widespread inversion rituals and ritual desecrations, which should settle once and for all the debate about whether or not the Sudanese counterinsurgency constitutes genocide: 
The Janjaweed militias don't distinguish at all between whether it's a baby, a woman or whether it's a man. The difference is what they do to them. If it's a man they're often castrated and then executed. Sometimes sexually assaulted before being executed.

They take kids and throw them in the air and catch them on bayonets. They smash little kids' faces in. They will take the children from the mothers and throw them into the huts while they're burning so that [the mothers] can hear the children screaming. There have been stories of women who have been pregnant and have been cut open and had the babies taken out. ${ }^{22}$

These are just a few examples from thousands that highlight the similarities in the treatment of pregnant women and babies during genocides. They show that because genocide is a crime targeting the life force of groups, in discussing it, we must look at more than the individual, on the one hand, and the larger ethnic, religious, or national group, on the other. In between the two stands the family unit, and for génocidaires, it is a major theatre for enacting their ultimate preoccupations. Because the family plays such an important role in the genocidal process, we risk missing one of the most agonizing aspects of victims' experiences of genocide when we categorize victims individually, solely based on sex, age, profession, or ethnicity rather than familial status. We also risk overlooking key markers of genocidal violence.

Given the importance of the destruction of families in the lives of genocide survivors, it is hard to explain why the perpetrators' treatment of the family unit at times of genocide has received such little sustained scholarly attention. ${ }^{23}$ Perhaps we simply assume violence against families during times of genocide because the family is a core institution of the groups targeted by the crime of genocide. Families reproduce groups-so, in studying the destruction of "national, ethnical, racial, and religious" groups as such, we are studying families by default. Another factor is that the social sciences have not paid a great deal of attention to families. More interested in the organization of production than reproduction, social scientists by and large were "inclined to see [reproduction] as responding, like everything else, to the material forces reshaping our world." ${ }^{24}$ The process of reproduction was not, in and of itself, an important line of inquiry, and the family therefore tended to be assumed in studies of genocide as other historical phenomena.

Another reason that genocidal violence against families goes unrecognized as a discernable type of atrocity is that families are largely absent from the international legal documents relevant to genocide. Raphael Lemkin's oft-quoted definition of genocide, from Axis Rule in Occupied Europe, does not mention the family. There he defines genocide in the following way:

Generally speaking, genocide does not necessarily mean the immediate destruction of a nation, except when accomplished by mass killings of all members of a nation. It is intended rather to signify a coordinated plan of different actions aiming at the destruction of essential foundations of the life of national groups, with the aim of annihilating the groups themselves. The objectives of such a plan would be disintegration of the political and social institutions, of culture, language, national feelings, religion, and the economic existence of national groups, and the destruction of the personal security, liberty, health, dignity, and even the lives of the individuals belonging to such groups. Genocide is directed against the national group as an entity, and the actions involved are directed against individuals, not in their individual capacity, but as members of the national group. ${ }^{25}$

Here we have individuals, on the one hand, and the national group on the other. The family unit is perhaps assumed under the rubric of "social institutions," though 
Lemkin does not mention it in his subsequent discussion. In this understanding, which has structured our concept of genocide both legally and sociologically, inversion rituals and mutilations of symbols of generation are to be understood according to their individual or their larger group attributes-in other words, they fall under the definition of torture of individual persons and the attempted genocide of a group. Neither of these frameworks is sufficient to fully recognize and understand the motivated assault on people's most cherished personal bonds and relationships.

The fact is that much genocidal violence is committed through the small-scale institution of the family. Génocidaires often find their targets in family situations and take advantage of this to inflict the most severe tortures imaginable, essentially using the individual family as a symbolic stand-in for the group to be destroyed. But, despite the family-based location of much life force atrocity, the identification of genocides still tends to focus solely on the large-scale violence directed at the group. ${ }^{26}$ This makes early identification of a potential genocide almost impossible and the final determination of genocide contingent upon large numbers or percentages of dead. One consequence of this is that cases in which a genocide was halted-such as in the case of the NATO intervention in Kosovo-there is little means of establishing empirically the presence of a specifically genocidal logic without access to clear statements of genocidal intent from the highest state and military authorities.

Focusing on families as the immediate representatives of the victim group can help us identify genocidal elements early on in conflicts, within smaller-scale massacres, before they reach the enormous proportions usually necessary to claim genocide. If we have a term like "life force atrocity" that we can use when we hear of the presence of inversion rituals and ritual desecrations within the context of war and occupation, we will have a powerful policy tool for identifying early-stage genocides. In the case of Serb aggression in Kosovo, testimonies of women survivors of gang rapes are full of examples of genocidal inversion rituals. Two examples gathered by Human Rights Watch show how the presence of inversion rituals can help us identify the presence of a genocidal logic targeting a group's generative powers through the exploitation of family relationships and symbols of reproduction. ${ }^{27}$ In one, a woman was raped in a room adjacent to her other family members, including several children, and then brought back into the room and killed at point-blank range in front of them:

They took my sister-in-law into the front room, and they were hitting her and telling her to shut up. The children were screaming, and they also screamed at the children. She was with the paramilitary for one half- hour. She was resisting, and they beat her, and the children could hear her screaming. I could only hear what was going on. I heard them slapping her. The children did not understand that they were raping her. After they raped my sister-in-law, they put her in line with us and shot her.

In another, a pregnant woman was taken from her mother and young child and raped, in the course of which her tormenters attempted to force the abortion of her child while mocking the sexual bond between husband and wife:

Because I was pregnant, they asked me where my husband was ... One of them said to another soldier, "Kick her and make the baby abort." They did this to me four times-they took me outside to the other place. Three men took me one by one. Then they asked me, "Are you desperate for your husband?" and said, "Here we are instead of him." 
Inversion rituals and violence against symbols of generation like these formed a pattern of attack in Kosovo alongside gang rapes, and, like gang rapes, they also "were used deliberately as an instrument to terrorize the civilian population, extort money from families, and push people to flee their homes." 28 Because they make explicit an intention on the part of the immediate perpetrators to destroy the generative powers and institutions of their victims, they can stand as powerful indicators of genocidal intent, especially in the context of a clear policy of ethnic cleansing.

\section{Women, Sexual Violence, and Life Force Atrocity}

As suggested by the two examples from Kosovo, when inversion rituals and ritual mutilations are reported, they most often appear in the record of women victims. This, too, may explain why violence against families has been so little highlighted as a subject for study in its own right. Women's experiences in general have not yet been fully mined for the insights they offer into genocidal processes. There are many reasons that women's experiences and testimonies might involve more violence against people specifically as members of families. Women are universal symbols of generation, and their bodies are therefore potent theatres for genocidal expressions of rage against the life force. Women also are universally accorded primary caretaking responsibilities for children, the elderly, and the household, roles that are culturally defined; therefore, their testimonies will tend to highlight the painful transgressions and betrayals of these roles by their tormenters. Moreover, as Adam Jones has shown, one early phase in most genocides is the separation of military-age men from the rest of the community, so the inversion rituals associated with genocidal violence will often involve women, their children, and elderly members of the household. $^{29}$ Also, male family members are more likely to leave home before violence reaches their communities to attempt to secure exit visas for family members, to join resistance forces, or to escape persecution, in the erroneous assumption that the women and children they leave behind will be spared. ${ }^{30}$

Whatever the reasons, women's testimonials offer deep insight into the logic of genocide. The testimonies of women survivors of Auschwitz, for example, are woven around the theme of family ties and familial loss. The survivor Isabella Leither explicitly draws the connection between the Nazis' violence against families and their genocidal aims throughout her memoir, Fragments of Isabella. Perhaps her most direct identification of Auschwitz with the murder of life force itself is in her description of the birth-and murder_of a baby in the camp:

The little baby born yesterday, whose mother remained alive because her pregnancy was not noticed, is off now to the crematorium. She was born only to die immediately. What was your hurry, little baby? Couldn't you have waited until the house painter was dead, so you could have lived? Couldn't the gods have arranged for a longer pregnancy so that evil, not life, would be murdered? For a moment, for just a moment, we had a real smell of a real life, and we touched the dear little one before she was wrapped in a piece of paper and quickly handed to the Blockelteste so the SS wouldn't discover who the mother was, because then she, too, would have had to accompany the baby to the ovens. Are we ever to know what life-giving feels like? Not here. Perhaps out there, where they have diapers, and formulas, and baby carriages-and life. ${ }^{31}$

Later in her memoir, Leitner laments the death of a young girl by highlighting the loss of future children that her death signifies: 
Rest in peace, young girl. The flickering stars above must be the weeping children of your womb. The womb, the glorious womb, the house that celebrates life, where life is alive, where the bodies of young girls are not carried out into the night. ${ }^{32}$

And, finally, Leitner locates her own resistance to the Nazis' final solution in her birth-giving powers:

Mama, Mama, I'm pregnant!

Isn't that a miracle, Mama? Isn't it incredible, Mama?

I stood in front of the crematorium, and now there is another heart beating within that very body that was condemned to ashes. Two lives in one, Mama-I'm pregnant!

Mama, we've named him Peter. You know how much I like that name. It translates into stone, or rock. You were the rock, Mama. You laid the foundation. Peter has started the birth of the new six million.

Mama, you did not die! ${ }^{33}$

Like other women Holocaust survivors, Leitner writes about the Holocaust from the perspective of a person who is closely tied to the life-giving powers both of the European Jewish communities that were targeted by the Nazis and to the future of all humanity. This perspective offers us an important insight into what genocide is. From the point of view of a young Jewish woman in Auschwitz, the genocidal process emerges as a specific kind of violence that targets a group's generative powers in the process of seeking their wholesale annihilation. The ritualized violence against symbols of group reproduction appears here as an integral part of the genocidal process rather than the ancillary consequences of a genocidal policy.

Because of the close association of women with reproduction and with families, and because women are so often caring for children and the elderly at times of genocide, the body of scholarly work on genocide that has brought the most attention to family violence is the recent focus on the crimes that are most frequently committed against women, especially genocidal rape. The genocides in Bosnia and Rwanda, where sexual torture was such a central component of the violence, brought international attention to rape as a war crime. These genocides also raised awareness of a specifically genocidal type of rape, which includes sexual torture and mutilation, forced impregnation, and the attempt to compromise the reproductive capacity of male and female survivors. ${ }^{34}$ Almost always embedded within stories of genocidal rape are instances of ritual inversions and desecrations. So, for example, atrocities listed as instances of sexual violence by the US State Department's Atrocities Documentation Team in Darfur have included the following acts: ${ }^{35}$

- the killing of young children

- the use of infants as weapons against their parents

- the slashing of pregnant women's bellies and the murder of their babies

- the rape of people in front of other family members

- the mutilation of women's reproductive organs, including their breasts

In many cases, these acts were performed concomitantly with rapes; in others, they were performed without rape but were still understood under the rubric of rape.

The problem with embedding reports of life force atrocities within studies of sexual violence against women is that although life force atrocities may include rape, they are not derivative of this crime. Their origin lies in the genocidal mentality of the killers, who seek to destroy a group by targeting its life force. Further- 
more, when human rights watchdog groups associate these atrocities solely with the rape of women, they miss the way that evidence of genocide is embedded within cultural understandings of the family and the relationships that sustain it. So, if we were to treat such crimes solely as part of the rape of women, we run the risk of not fully appreciating the significance of this violence to our broader understanding of the nature of genocide as principally a crime preoccupied with generation, involving the entire community and its institutions of reproduction. It must be noted that the inversion rituals that characterize genocidal killing include many kinds of torture that involve and often single out men and boys, including their rape and sexual mutilation, the forced intercourse between family members, and the coerced killing of children by parents, or parents by children, in addition to a host of predatory tortures that involve a similar logic. ${ }^{36}$

\section{Life Force Atrocities and Cultural Beliefs about Reproduction}

Looking at genocide through the lens of life force atrocity exposes the important role played by culture in the ultimate form taken by genocidal policy. Génocidaires pursue annihilation in different ways that are inextricably linked to deeply held beliefs about social and biological reproduction. In other words, while the methods used by perpetrators to kill and torment their victims prey on universally cherished values and relationships, the exact form of the acts involved in such violence will differ according to cultural understandings of reproduction. This means that numbers of dead may not be the best evidence of genocide, since perpetrators may use means other than mass death to pursue the annihilation of the group, focusing instead on those institutions of reproduction that guarantee the groups' future.

In Bosnia, for example, women were often singled out for genocidal rape rather than outright murder because Serbian forces believed men were the defining element in ethnic reproduction. The bodies of Bosniak (and Croatian) women were seen as vehicles for the reproduction of future Serbian nationals and their reproductive powers were co-opted by génocidaires for use in the genocidal process. ${ }^{37}$ Forcible impregnation, alongside the incarceration of impregnated women up to their third trimester, was believed to be a means of destroying the group. In Nazi Germany, on the other hand, reproduction was understood according to the racialist interpretation of biology, in which women contributed to the "racial composition" of children. Accordingly, Jewish women and girls were believed to be important carriers of the "Jewish race" and were therefore targeted for indiscriminate slaughter along with Jewish men and boys. ${ }^{38}$ In the case of Rwanda, women had a double status; on the one hand, the essentialism of Hutu Power ideology determined that Tutsi women were considered to be innately, and sometimes quintessentially, Tutsi, even if they were married to Hutu men; Hutu perpetrators were therefore instructed to kill all Tutsi, male and female. On the other hand, given that women had taken their husbands' social identity at marriage, Tutsi women were sometimes understood to be "less Tutsi" than Tutsi men and frequently targeted for direct killing only after all the men in a community had been hunted down and killed. ${ }^{39}$

The presence of these rituals across genocides shows that while génocidaires physically target individual bodies for torture and killing, they do so in the context of targeting families as reproductive units by assaulting directly the bonds of love, trust, and tenderness that tie individuals to one another. Similarly, although men and women face sex-specific types of treatment during genocides, this gendered violence is often simultaneously aimed at other family members. In some cases, this logic has been expressed explicitly by génocidaires. So, for example, the famous 
RAM plan that was crafted by Serb officers in the Yugoslav army before the war framed terror and ethnic destruction in terms of family structures. According to Beverly Allen, one version of the RAM plan reasoned:

Our analysis of the behavior of the Muslim communities demonstrates that the morale, will, and bellicose nature of their groups can be undermined only if we aim our action at the point where the religious and social structure is most fragile. We refer to the women, especially adolescents, and to the children. Decisive intervention on these social figures would spread confusion ... thus causing first of all fear and then panic, leading to a probable retreat from the territories involved in war activity. ${ }^{40}$

Separating and killing "battle-aged men" in this context is a way of decapitating the family basis of the religious and social structure, much as the targeting of intellectuals is aimed at decapitating the institutional basis of the public life of a group. Men are killed to expose women and children, women are raped to humiliate men, children are tortured to destroy parents-this relational logic is the core of genocidal violence against families.

In stating this, I do not mean to erase the importance of sex-selective killing, of "gendercide," during genocides. ${ }^{41}$ I simply mean to point out that sex selection in and of itself can be also a way of torturing family members. As R. Charli Carpenter has recently noted, "Men and women are also indirectly victimized by harm to loved ones of the opposite sex, a point which should not be invalidated in attempting to define who the 'true victims' are." 42 She quotes Anne Goldstein, who, in writing about genocidal rape, notes that

men too are injured by the sexual assault of women for reasons untainted by offensive, antiquated notions of chivalry and ownership. To watch helplessly as someone you love is tortured may be as bad or worse than being tortured yourself, and international law should be able to reach and punish such crimes. ${ }^{43}$

Equally, women are victimized by harm done to the men in their lives. This is true because women love the men in their lives; it is true because women pride themselves on nurturing and protecting those around them; and it is true because in most societies, women gain rights, enjoy protection, and find economic security only or principally through the men in their lives.

Perpetrators know this and count on it. This may be an obvious point, but the implications of it have been underanalyzed. Perpetrators use the sacrosanct status of family relationships, and the tenderness and protectiveness that family members feel for one another, as a way to destroy their victims emotionally, spiritually, and psychically before engaging in their physical destruction in whole or in part. They know this and they appear to derive great satisfaction from doing this.

\section{Life Force Atrocities without Genocide?}

By way of conclusion, I would like to note that the particular forms of violence that I single out here as inherently genocidal are not necessarily confined to commonly recognized, root and branch, genocides. Inversion rituals and the ritual mutilation and desecration of sacred symbols of generation have been key features of recent wars in the Democratic Republic of Congo and Sierra Leone, to cite two examples from Africa. ${ }^{44}$ They also played a significant role in Japan's occupation of East Asia in World War II and were particularly evident in Japan's Imperial Army's sex slavery system. ${ }^{45}$ What does this mean about such violence being in and of itself evidence of genocidal intent? 
One way to look at this question is to place life force atrocities within the longerterm reproductive process. Life force atrocities aim to compress total annihilation, which occurs over time, into one moment of ultimate destruction in which a group is destroyed in its past, present, and future tenses through targeting its temporal symbols-pregnant women, infants, the elderly-and undermining the bonds necessary for group cohesion and therefore for biological and cultural reproduction. Because life force atrocities are committed in immediate and clearly circumscribed social and political spaces-in a household, a front yard, a village square, a military encampment, and so forth-they become, for the perpetrators, microcosms of the potentially massive crime itself. The perpetrators of these crimes may or may not be acting according from directives received from higher authorities. Genocidal intent need not be institutionalized in a state or military in order for it to exit. Generally speaking, however, such institutionalization is necessary for the crime to reach the mass proportions that we associate with it.

As the above discussion suggests, I believe that life force atrocities suggest that genocidal intent can be inferred before mass death. It can sometimes form rather quickly within the context of warfare or civil strife, and can be expressed in "limited" ways during these processes. Whether or not it becomes the main purpose of warfare will depend on many factors, including the nature of the regimes engaged in hostilities. Genocidal intent can appear and thrive on the peripheries of an armed force without having been ordered or organized by a particular state or military leadership. When the ethos of destruction exceeds the pragmatic task of defeating the enemy armed forces, and instead begins to form a military culture that sets itself up against civilian life, eschewing as effeminate the relations and institutions of affection that are the key to human survival, then it is easy for genocidal thinking to creep in. What we recognize as atrocities against civilians can be a sign of an emerging genocidal logic within small units of soldiers or an entire army-whether directed from above or not-if such atrocities show a patterned obsession with symbols of family integrity and generative power. In such cases, the existence of such violence suggests that perpetrators have begun to form a concept of the victim group that has the same logic as those historical group categories identified by the Genocide Convention, even in those cases where the victim group does not easily conform to any of the common definitions of a "national, ethnical, racial, or religious" group.

Incorporating the concept of life force atrocity into our understanding of the crime of genocide will allow us to approach the plain language of the Genocide Convention in an historically informed way, thereby better capturing the intended meaning of the convention's recognized victim groups than is offered by overly literal and ahistorical interpretations that seek to determine whether a victim group is indeed, by virtue of some social-scientific criteria, "national, ethnical, racial, or religious" in nature. When killers begin to incorporate life force atrocities into their repertoire of killing techniques, we can be on the alert for a genocide-in-the-works, even in cases where the victims appear from the outside to constitute a political or social group, or an economic class. If the perpetrators, by engaging in inversion rituals and ritual desecrations, demonstrate that they are targeting victims' generative forces, I think we can be fairly safe in assuming that they have developed, at some level of their organizational hierarchy, a concept of the victim group as an "organic collectivity," to use Scott Straus's very useful formulation. ${ }^{46}$

In the case of Sierra Leone, where inversion rituals were widespread, the implications for the twenty-first century are very serious. In this case, the rebel militias committed genocidal violence against civilians frequently without regard to ethnicity. 
Indeed, the identities that seemed most formative of the violence distinguished between members of the fighting cadres on the one hand, and everyone else on the other. Revolutionary United Front (RUF) soldiers therefore targeted families for unspeakable cruelties regardless of their affiliation with any specific group recognized by the Genocide Convention. The presence of inversion rituals and ritual mutilations and desecrations here can be seen as a kind of omnicide, to use the term coined by Israel Charny to refer to a nuclear holocaust and other such threats to human life. In other words, life force atrocities have the potential to constitute an assault on generative powers as such, which means that the violence will become universalized, destroying anybody outside of the perpetrator cadre. ${ }^{47}$ So, in the case of Sierra Leone, the children who were forced to kill their own parents before being kidnapped to serve as RUF members were given this hideous task not simply to create cold-blooded murderers out of them in the name of enhancing the RUF's chances of achieving certain political and economic ends, but also to initiate them into the genocidal violence that was the core feature, and in some cases the core purpose, of RUF fighting. A similar logic seems to be behind the life force atrocities documented in the eastern regions of the Democratic Republic of Congo. In these cases, the ritual repetition of life force atrocity becomes, for some soldiers, a primary goal of the fighting itself.

This suggests that genocide always threatens omnicide, and that, perhaps, within the particular group crime of genocide lies the more universal crime of what Nuremberg prosecutor François de Menthon called "crimes against the human status." 48 In other words, genocide, a crime focused against the human status of specific groups, is simultaneously, because of the universality of our generative process, a crime against the continuation of the human species as such. Certainly we know that perpetrators' definitions of target groups are capacious and consequently able to expand to include entirely new sets of victims. In this way, the intent to destroy the life force of one group can spread to destructive actions aimed against the life force more generally, a tendency that has expressed itself in scenarios like the warfare in Sierra Leone and the DRC and in state attempts to coercively manipulate reproduction within its supposedly "favored" groups. Indeed, perpetrators' hostility to the life force may, in fact, predate the implementation of genocidal strategies against specific groups.

This latter possibility was raised by Hannah Arendt in her analysis of the trial of Adolf Eichmann. She wrote that

[h] ad the court in Jerusalem understood that there were distinctions between discrimination, expulsion, and genocide, it would immediately have become clear that the supreme crime it was confronted with, the physical extermination of the Jewish people, was a crime against humanity, perpetrated upon the body of the Jewish people, and that only the choice of victims, not the nature of the crime, could be derived from the long history of Jew-hatred and anti-Semitism. ${ }^{49}$

While historical categories and processes will determine how genocide plays itself out in the here and now, the crime itself predates all historical category formation and is bound up with a rejection of the human status as such. The way in which this linkage between the particular and the general works in the perpetrators' conceptualization and commission of genocide is something that needs to be researched in much greater depth.

Whatever the final analysis about the relationship between genocide and more generalized, omnicidal tendencies, outlying cases suggest the possibility that, in the 
twenty-first century, more and more genocidal violence will be the product of quasistate and non-state actors. This means that genocide has the potential to proliferate much more rapidly than in a system where states are the principal agents. There is growing evidence that today's génocidaires are sharing knowledge and strategies, an issue that is vital to global security given the astronomical increase in the presence of mercenaries in conflict situations. The original Janjaweed militias in Darfur, for example, share a Libyan connection with the former president of Liberia, Charles Taylor, who terrorized the Liberian population and backed RUF leader Foday Sankoh, whom Taylor had met in a Libyan training camp in the 1970 s. ${ }^{50}$ Serbian mercenaries are reported to have committed atrocities in the Democratic Republic of Congo. ${ }^{51}$

Because genocide is rarely self-limiting, it is imperative that we learn to recognize genocidal patterns outside of state-sponsored genocides before we are presented with large numbers of dead. Life force atrocities offer one way of identifying evidence of possible genocide in the absence of clear statements on the parts of belligerents, and it can help analysts overcome accusations that the use of the term "genocide" is nothing more than a (highly politicized) matter of semantics. Precisely because of its destructive engagement with life forces, genocide tends to spread out from an initial target group and become an end in itself, a lifestyle, even, eventually causing massive suffering and regional instability. Because life force atrocities are the cause of such indescribable suffering and life-long trauma to survivors and their descendants, they demand swift intervention once they have been shown to constitute a pattern of warfare and communal violence.

\section{Acknowledgments}

I would like to thank Adam Jones and the anonymous reviewers at Genocide Studies and Prevention for their very helpful comments on drafts of this article.

\section{Notes}

1. Terri Jo Ryan, "Family Tree Tied to Forgotten Genocide," Waco Tribune-Herald, Sunday, 24 April 2005, http://www.aarweb.org/programs/awards/journalism_awards/winners/ 2006ryan.pdf (accessed 25 January 2010).

2. My use of the term "desecration" is drawn from Michael Sells' discussion of the treatment of Bosniak women by Serbian forces, something he also terms "gynocide." See Michael Sells, The Bridge Betrayed: Religion and Genocide in Bosnia (Berkeley: University of California Press, 1996).

3. See, for example, Stephen A. Kostas, "Making a Determination of Genocide in Darfur," in Genocide in Darfur: Investigating the Atrocities in the Sudan, ed. Samuel Totten and Eric Markusen, 111-26 (New York: Routledge, 2006).

4. For an overview of this work, see Adam Jones, "Gender and Genocide," in The Historiography of Genocide, ed. Dan Stone (Cambridge: Cambridge University Press, forthcoming).

5. Quoted in Roméo Dallaire, Shake Hands with the Devil (New York: Carroll and Graf, 2003), 462. The original quote is from Khan's memoir of the genocide, The Shallow Graves of Rwanda (London: I.B. Tauris, 2000), 16.

6. Robert-Jan van Pelt, "A Site in Search of a Mission," in Anatomy of the Auschwitz Death Camp, ed. Yisrael Gutman and Michael Berenbaum, 93-156 (Bloomington: Indiana University Press, 1994); Terrence Des Pres, The Survivor: An Anatomy of Life in the Death Camps (New York: Oxford University Press, 1976).

7. Daniel Goldhagen, Hitler's Willing Executioners (New York: Alfred A. Knopf, 1996), 308.

8. Helena Kubica, "Children," in Anatomy of the Auschwitz Death Camp, ed. Yisrael Gutman and Michael Berenbaum, 412-27 (Bloomington: Indiana University Press, 1994).

9. Goldhagen, Hitler's Willing Executioners, 308-9. 
10. Ibid., 309.

11. Stanley Tambiah, "A Performative Approach to Ritual," in Culture, Thought, and Social Action: An Anthropological Perspective (Cambridge, MA: Harvard University Press, 1985), 129. Quoted from M.E. Combs-Schilling, Sacred Performances: Islam, Sexuality, and Sacrifice (New York: Columbia University Press, 1989), 29.

12. See especially Maurice Bloch, From Blessing to Violence: History and Ideology in the Circumcision Ritual of the Merina of Madagascar (New York: Cambridge University Press, 1986), and Victor Turner, The Ritual Process: Structure and Anti-Structure (Ithaca, NY: Cornell University Press, 1977).

13. Victor Turner, "Liminality and Communitas," in The Ritual Process: Structure and AntiStructure, 94-130 (Ithaca, NY: Cornell University Press, 1977).

14. Jean Hatzfeld, Machete Season: The Killers in Rwanda Speak, trans. Linda Coverdale (New York: Picador, 2003), 94-95.

15. For a discussion of the role of transgression in genocidal violence, see Dan Stone, "Genocide as Transgression," in History, Memory, and Mass Atrocity: Essays on the Holocaust and Genocide, 196-216 (Portland, OR: Vallentine Mitchell, 2006). For perpetrator testimony regarding the festive nature of killing, see Hatzfeld, Machete Season, and Goldhagen, Hitler's Willing Executioners, esp. 451-53.

16. Christopher R. Browning, Ordinary Men: Reserve Battalion 101 and the Final Solution in Poland (New York: HarperPerennial, 1998), esp. chapter 14, “The Jew Hunt" (121-32).

17. Here I am assuming the culturally constructed (though in part biologically determined) nature of what we call the "family," in line with the anthropologist A.F. Robertson, who writes that "[f]amilies ... are not mutually exclusive, objectively definable groups of people out there in society. They are overlapping components of a huge network of relationships which is created through time out of the basic process of reproduction." A.F. Robertson, Beyond the Family: The Social Organization of Human Reproduction (Berkeley: University of California Press, 1991), 7.

18. Alan Jacobs, "Aspects of Survival: Triumph over Death and Onliness," IDEA: A Journal of Social Issues 2 (January 1997), http://www.ideajournal.com/articles.php?id=11 (accessed 25 January 2010).

19. Fred Pelka, "Voices from a War Zone (a Writer's Experiences in Croatia)," The Humanist, 1 March 1995, http://findarticles.com/p/articles/mi_m1374/is_n2_v55/ai_17047276/pg_2/?tag= content;col1 (accessed 25 January 2010).

20. For example, see the testimony of Khanum Palootzian on her experiences during the Armenian genocide, at http://www.teachgenocide.org/files/Witnesses\%20to\%20the\% 20Armenian\%20Genocide.pdf.

21. Catharine A. MacKinnon, "Turning Rape into Pornography: Postmodern Genocide," Ms., July/August 1993, 24-30.

22. Shawn Adler, “The Darfur Genocide: A Witness Account and How You Can Help,” http:// www.mtv.com/news/articles/1560981/20070601/index.jhtml (accessed 25 January 2010).

23. A notable exception is Helen Fein, "Genocide and Gender: The Uses of Women and Group Destiny,” Journal of Genocide Research 1:1 (1999), 43-63.

24. Robertson, Beyond the Family, 2.

25. Raphael Lemkin, Axis Rule in Occupied Europe (Washington, DC: Carnegie Endowment for International Peace, 1944), 79, http://www.preventgenocide.org/lemkin/AxisRule19441.htm (accessed 25 January 2010).

26. Stuart Stein, "Geno and Other Cides: A Cautionary Note on Knowledge Accumulation," in Gendercide and Genocide, ed. Adam Jones, 198-208 (Nashville, TN: Vanderbilt University Press, 2004).

27. Human Rights Watch, Serb Gang-Rapes in Kosovo Exposed (21 March 2000), http:// www.hrw.org/en/news/2000/03/20/serb-gang-rapes-kosovo-exposed (accessed 25 January 2010).

28. Ibid. 
29. For a summary of Adam Jones's work on the subject see Adam Jones, "Gender and Gendercide," in Gendercide and Genocide, ed. Adam Jones, 1-38 (Nashville, TN: Vanderbilt University Press, 2004). See also Gendercide Watch, http://www.gendercide.org.

30. For the Holocaust see Gisela Bock, "Einführung," in Genozid und Geschlecht: Jüdische Frauen im nationalsozialistischen Lagersystem, ed. Gisela Bock, 10 (Frankfurt: Campus Verlag, 2005). For Rwanda, see Adam Jones, "Gender and Genocide in Rwanda," in Gendercide and Genocide, ed. Adam Jones, 98-137 (Nashville, TN: Vanderbilt University Press, 2004), 116.

31. Isabella Leitner, Fragments of Isabella: A Memoir of Auschwitz (New York: Laurel, 1978), 58.

32. Ibid., 68.

33. Ibid., 105.

34. Siobhan K. Fisher, "Occupation of the Womb: Forced Impregnation as Genocide," Duke Law Journal 46 (1996): 91-133.

35. Kelly Dawn Askin, "Prosecuting Gender Crimes Committed in Darfur," in Genocide in Darfur: Investigating the Atrocities in the Sudan, ed. Samuel Totten and Eric Markusen, 141-62 (New York: Routledge, 2006), 146-48.

36. For more on the sexual torture of men as a sign of genocide, see Adam Jones and Sandesh Sivakumaran, "Sexual Violence against Males: A Genocidal Strategy?" (Paper presented at the 2007 IAGS Conference, Sarajevo, BiH, 12 July 2007).

37. Vesna Nikolic-Ristanovic, "Sexual Violence," in Women, Violence and War: Wartime Victimization of Refugees in the Balkans, trans. Borislav Radovic, 65-73 (Budapest: Central European University Press, 2000); Alexandra Stiglmayer, ed., Mass Rape: the War against Women in Bosnia-Herzegovina (Lincoln: University of Nebraska Press, 1994); Beverly Allen, Rape Warfare: The Hidden Genocide in Bosnia-Herzegovina and Croatia (Minneapolis: University of Minnesota Press, 1996); Euan Hague, "Rape, Power and Masculinity: The Construction of Gender and National Identities in the War in BosniaHerzegovina," in Gender and Catastrophe, ed. Ronit Lentin, 50-63 (London: Zed Books, 1997).

38. Michael Burleigh and Wolfgang Wipperman, The Racial State (Cambridge: Cambridge University Press, 1993), esp. chapter 4, "The Persecution of the Jews" (77-112).

39. Jones, "Gender and Genocide in Rwanda," 111.

40. Quoted in Mark Danner, "America and the Bosnia Genocide," New York Review of Books, 4 December 1997, http://www.nybooks.com/articles/989 (accessed 25 January 2010) (original emphasis). Although Danner does not footnote his source, the passage is quoted from Beverly Allen, Rape Warfare: The Hidden Genocide in Bosnia-Herzegovina and Croatia (Minneapolis: University of Minnesota Press, 1996), 57.

41. On "gendercide," see Jones, "Gendercide and Genocide"; Mary Anne Warren, Gendercide: The Implications of Sex Selection (Totowa, NJ: Rowman and Allanheld, 1985).

42. R. Charli Carpenter, "Beyond 'Gendercide': Operationalizing Gender in Comparative Genocide Studies," in Gendercide and Genocide, ed. Adam Jones, 230-56 (Nashville, TN: Vanderbilt University Press, 2004), 244.

43. Quoted in Carpenter, ibid., 244. Originally from Anne Tierney Goldstein, Recognizing Forced Impregnation as a War Crime (New York: Center for Reproductive Law and Policy, 1994), 22.

44. The Final Report of the Truth and Reconciliation Commission of Sierra Leone (2007), http://www.sierra-leone.org/TRCDocuments.html (accessed 25 January 2010); Human Rights Watch, Seeking Justice: The Prosecution of Sexual Violence in the Congo War (2005), http://hrw.org/reports/2005/drc0305/index.htm (accessed 25 January 2010).

45. See, e.g., Iris Chang, The Rape of Nanking: The Forgotten Holocaust of WWII (New York: Basic Books, 1997); Sangmie Choi Schellstede, ed., Comfort Women Speak: Testimony by Sex Slaves of the Japanese Military (New York: Holmes \& Meier, 2000); Yoshiaki Yoshimi, Comfort Women (New York: Columbia University Press, 2002). 
46. Scott Straus, "Contested Meanings and Conflicting Imperatives: A Conceptual Analysis of Genocide," Journal of Genocide Research 3 (2001): 349-75. Straus argues that “'genocide' might be redefined as an organized attempt to annihilate a group that a perpetrator constitutes as an organic collectivity" (367; emphasis added).

47. Charny defines "omnicide" in the following way: "Omnicide refers to simultaneous intentional genocide against numerous races, nations, religions, etc." Israel W. Charny, "Towards a Generic Definition of Genocide," in Genocide: Conceptual and Historical Dimensions, ed. George J. Andreopoulos, 76 (Philadelphia: University of Pennsylvania Press, 1994).

48. International Military Tribunal, Trial of the Major War Criminals before the International Military Tribunal, Nuremberg, 14 November 1945, 42 vols. (Nuremberg: International Military Tribunal, 1947), vol. 5: 407-9. Quoted from Michael R. Marrus, The Nuremberg War Crimes Trial, 1945-46: A Documentary History (Boston: Bedford St. Martin's, 1997), 190-91.

49. Hannah Arendt, Eichmann in Jerusalem: A Report on the Banality of Evil (1963; reprint, New York: Penguin, 1994), 269 (emphasis added).

50. Julie Flint and Alex de Waal, "The Arab Gathering," in Darfur: A Short History of a Long War, 49-57 (London: Zed Books, 2005); Rene Wadlow, "Charles Taylor in Sierra Leone: Was It More Than Money?” L'Occidentale, 5 June 2006, http://towardfreedom.com/ home/content/view/832/63/ (accessed 25 January 2010); "I Spoke to Ghadaffi about Revolutionary Ideas," Liberian Daily Observer, 20 November 2009, http://www.loccidental. net/\%E2\%80\%9Ci-spoke-to-ghadaffi-about-revolutionary-ideas\%E2\%80\%9D/ (accessed 25 January 2010).

51. UN General Assembly, Report of the Joint Mission Charged with Investigating Allegations of Massacres and Other Human Rights Violations Occurring in Eastern Zaire (now Democratic Republic of the Congo) since September 1996, UN Doc. A/51/942 (2 July 1997), http://www.unhchr.ch/Huridocda/Huridoca.nsf/0/bb0a99b02d16ddd280256724005e2200? Opendocument (accessed 25 January 2010). 